\title{
Methodical for the decommissioning of generating units for modernization from the position of ensuring the adequacy of electric power systems
}

\author{
Dmitry Krupenev ${ }^{1, *}$, Gennady Kovalev ${ }^{1}$, and Ludmila Lebedeva ${ }^{1}$ \\ ${ }^{1}$ Melentiev Energy Systems Institute of Siberian Branch of the Russian Academy of Sciences, 664033, Irkutsk, Lermontov 130 st.
}

\begin{abstract}
The article presents a methodical for determining the procedure for decommissioning for the purpose of modernizing generating equipment while ensuring the highest possible level of adequacy of electric power systems (EPS). The model for assessment of the adequacy of EPS is basis of the methodical. We can choose the most effective option for decommissioning generating units from the standpoint of ensuring the adequacy of EPS using the methodical. The effectiveness of the proposed methodical is shown In the final part of the article.
\end{abstract}

\section{Introduction}

The operational experience of technical equipment, including generating equipment, shows that it wears out and needs to be repaired or replaced. The main requirement is to increase the efficiency of the facility when we carrying out these operations. This can be ensured by the modernization of equipment based on the latest achievements of scientific and technological progress. At the same time, the challenge arises in the electric power systems (EPS) themselves to create conditions that allow for modernization work related to the decommissioning of equipment for quite long periods (up to a year or more). In some cases, a power and energy reserve should be provided for in the EPS to carry out equipment modernization.

The problem of modernization of power equipment for the Russian electric power industry is very urgent. The presence of significant volumes of generating equipment, worn out morally and physically is the reason for this. Thermal power plants (TPP) are very worn out. This equipment reduces the efficiency in the power systems, leads to an increase of the cost of electricity. Currently, a procedure has been organized at the state level for the modernization of obsolete generating equipment at TPPs in the Unified Energy System of Russia [1-3]. At the same time, modernization implies the decommission of generating units for a long period of up to 2 years [2]. This affects the reliability level of the power systems. In [3], criteria for the selection of projects for the modernization of each type of TPP equipment and the rules for the interaction of electricity market entities during selection are presented in detail. The purpose of this article is to develop a methodic for determining the procedure for decommissioning for the purpose of modernizing generating equipment while ensuring the highest possible level of adequacy of EPS. In this case, all the technical characteristics of EPS development schemes necessary for assessing the adequacy [4-5] and the composition of the generating equipment, which must be modernized for a certain period of time, should be known.

\section{Methodic for the decommissioning of generating units for modernization from the position of ensuring the adequacy of electric power systems}

The initial action to justify the decommissioning of generating equipment for modernization is the formulation of withdrawal criteria. In $[1,3]$ the following criteria are formulated:

- lifetime;

- demand for power of a generating facility in the power system.

It is also advisable to attribute to the decision-making criteria for the decommissioning of an facility for modernization:

- specific fuel consumption for electricity generation;

- the volumes of unplanned and emergency repairs.

All criteria should be converted into weighting coefficients and integrated into one complex criterion, which should be compared with an economically feasible threshold value. Non-compliance of the actual value of the criterion with the threshold value is the rationale for the decommissioning of equipment for modernization. It is also advisable in the future to develop a system for forecasting the criterion of modernization in order to develop long-term plans for the modernization of generating equipment.

We need the features of the functioning of energy systems should be taken into account when

* Corresponding author: krupenev@,isem.irk.ru 
decommissioning equipment for modernization. The main of which are:

- modernization of generating units of thermal power plants should be carried out during the period of the valley of the peak load schedule;

- for heating equipment, it is necessary to provide for the possibility of modernization outside the heating period;

- if there are hydroelectric power plants (HPPs) in the power system, it is necessary to take into account that during the flood period, the HPP can compensate for the retired capacity for modernization.

These features can be comprehensively taken into account when assessing the adequacy of EPS. Adequacy indicators can be signals of determining the best time frame for modernization. We can use indicators such as the probability of a fail-free operation and the mathematical expectation of under-supply of electricity.

The result of modernization of generating equipment is increase of the efficiency and demand of the generating unit in the electricity and capacity market.

The methodic for determining the procedure for decommissioning for the purpose of modernizing generating equipment while ensuring the highest possible level of adequacy of the EPS is a sequence of the following actions:

1. Assessment of the adequacy of the initial plan of the development of the EPS for the period allotted for the modernization of generating equipment, without decommissioning generating units for modernization. A methodic based on the Monte Carlo method is used to assessment of the adequacy. The probability of a failfree operation and the mathematical expectation of under-supply of electricity is a result for each month of the billing period.

2. Analysis of the values of the probability of failfree operation in each month and in each EPS (reliability zone) in which the generating equipment selected for modernization is located. Identification of the sequence of months with the highest integral of fail-free probability of a job without deficiency. Moreover, the sequence of months should be equal to the number of months that are required for the modernization of the generating facility with the worst value of the modernization criterion.

3. Assessment of the adequacy of the EPS development option for the period allotted for the modernization of generating equipment, with the decommissioning of the generating unit for modernization.

4. Repeat the second and third stages of this methodic until all generating equipment intended for modernization is taken into account.

According to the results of the compilation of a schedule for modernization of generating equipment, it may turn out that the probability of deficit-free operation in the EPS is low, which does not meet the requirements of electricity consumers for ensuring reliability. In this case, there are several options for solving this problem:

1. If it is technically possible to postpone the modernization dates to later ones, then it is advisable to change the modernization period for some generating facilities.

2. If the forecast schedule for the modernization of generating equipment is relatively "tight" and there is no possibility to postpone the date of modernization, then for the considered EPS, as part of the design for its development, it is necessary to provide an additional reserve of generating capacity to compensate for decommissioning of generating equipment for modernization purposes. The considered excess power is not a part of the power providing the adequacy of the EPS. Additional excess power in large complex EPSs should be evaluated taking into account the place of its placement in the system, the type and parameters of this power, including its reliability.

\section{Experimental research}

Experimental calculations were carried out according to the scheme of the interconnected power system (IPS) of Siberia. The IPS scheme of Siberia for this research is due to inaccurate source data. The calculations do not pretend to specific recommendations, but are indicative, justifying the proposed methodic. These calculations can be characterized as test ones.

The calculated scheme of Siberia IPS is shown in Figure 1.

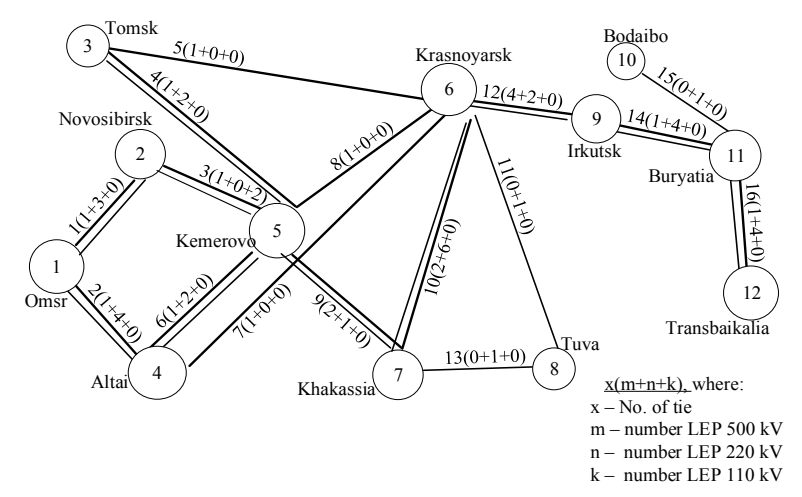

Fig. 1. The calculated scheme of the Siberia IPS.

The main initial data and the results of assessing the adequacy of the initial version of the development of the Siberia IPS (the first step of the methodic for determining the order) are presented in tables 1 and 2 .

As can be seen from table 2, in almost all EPS, the values of the probability of deficit-free operation are higher than 0.996 , with the exception of those that we call problem power systems. These EPS have their own deficit of generating capacity and insufficient bandwidth of connections with neighboring EPS. The reserve of the system as a whole is $12 \%$, which corresponds to that recommended in [6]. In the initial version, $12 \%$ was achieved by reducing the available capacity at hydroelectric power plants. 
Table 1. Initial information and the resulting indicators for assessing the adequacy of the initial version (without the output of units for modernization.

\begin{tabular}{|c|c|c|c|c|}
\hline \multirow[t]{2}{*}{ No. node } & \multirow[t]{2}{*}{$\begin{array}{c}\text { Available } \\
\text { power, } \\
\text { MW }\end{array}$} & \multirow{2}{*}{$\begin{array}{c}\text { Absolute } \\
\text { maximu } \\
\text { m of load, } \\
\text { MW }\end{array}$} & \multicolumn{2}{|c|}{$\begin{array}{l}\text { Own power } \\
\text { reserve }\end{array}$} \\
\hline & & & MW & $\begin{array}{l}\text { \% of } \\
\text { Рмax }\end{array}$ \\
\hline 1 & 1479 & 1894 & -415 & $-21,91$ \\
\hline 2 & 2730 & 2894 & -164 & $-5,67$ \\
\hline 3 & 918 & 1732 & -814 & -47 \\
\hline 4 & 1444 & 1918 & -474 & $-24,71$ \\
\hline 5 & 5028 & 4637 & 391 & 8,43 \\
\hline 6 & 11007 & 7738 & 3269 & 42,25 \\
\hline 7 & 4680 & 2185 & 2495 & 114,19 \\
\hline 8 & 39 & 218 & -179 & $-82,11$ \\
\hline 9 & 9670 & 9526 & 144 & 1,51 \\
\hline 10 & 20 & 90 & -70 & $-77,78$ \\
\hline 11 & 898 & 1029 & -131 & $-12,73$ \\
\hline 12 & 1156 & 1468 & -312 & $-21,25$ \\
\hline IPS & 39069 & 35329 & 4186 & 12,00 \\
\hline
\end{tabular}

Table 2. Initial information and the resulting indicators for assessing the adequacy of the initial version (without the output of units for modernization.

\begin{tabular}{|c|c|c|}
\hline $\begin{array}{c}\text { No. } \\
\text { node }\end{array}$ & $\begin{array}{c}\text { Probability of a fail- } \\
\text { free operation }\end{array}$ & $\begin{array}{c}\text { The m.e. of under- } \\
\text { supply of } \\
\text { electricity MW } \mathbf{~ h}\end{array}$ \\
\hline 1 & 0,993505 & 12202,4 \\
\hline 2 & 0,998538 & 208,2 \\
\hline 3 & 0,998465 & 442,6 \\
\hline 4 & 0,99853 & 201,1 \\
\hline 5 & 0,998551 & 242,1 \\
\hline 6 & 0,998527 & 307,2 \\
\hline
\end{tabular}

\begin{tabular}{|c|c|c|}
\hline 7 & 0,998848 & 202,9 \\
\hline 8 & 0,998127 & 1079,6 \\
\hline 9 & 0,998313 & 1658,2 \\
\hline 10 & 0,808054 & 8292,8 \\
\hline 11 & 0,996902 & 1566,7 \\
\hline 12 & 0,940244 & 56656,4 \\
\hline IPS & 0,782396 & 83060,1 \\
\hline
\end{tabular}

Table 32 presents the plans for the decommissioning of generating units of the Siberian IPS for modernization for 2023-2025 according to [1-3].

Further, according to the methodic for determining the procedure of decommissioning for the purpose of modernizing generating equipment while ensuring the highest possible level of adequacy of EPS for each year under consideration, a procedure was established for decommissioning generating units. The results were compared with the decommissioning procedure of generating units, presented in table 3.

Table 3. Schedule for the modernization of units at power plants of the Siberia IPS.

\begin{tabular}{|c|c|c|c|c|c|}
\hline $\begin{array}{l}\text { No. } \\
\text { no } \\
\text { de }\end{array}$ & $\begin{array}{c}\text { Name of } \\
\text { generating } \\
\text { facility }\end{array}$ & $\begin{array}{c}\text { Equipm } \\
\text { ent } \\
\text { station } \\
\text { number }\end{array}$ & $\begin{array}{c}\text { Install } \\
\text { ed } \\
\text { capaci } \\
\text { ty of } \\
\text { the } \\
\text { unit, } \\
\text { MW }\end{array}$ & $\begin{array}{c}\text { Mode } \\
\text { rnizat } \\
\text { ion } \\
\text { Start } \\
\text { Date }\end{array}$ & $\begin{array}{c}\text { Nu } \\
\text { mbe } \\
\text { r of } \\
\text { mo } \\
\text { nths }\end{array}$ \\
\hline \multicolumn{6}{|c|}{2023} \\
\hline 5 & $\begin{array}{l}\text { Tom-Usinsk } \\
\text { SDPS }\end{array}$ & TG-7 & 200 & $\begin{array}{c}01.01 . \\
2023\end{array}$ & 18 \\
\hline 6 & $\begin{array}{l}\text { Krasnoyarsk } \\
\text { TPP } 2\end{array}$ & TG-1 & 110 & $\begin{array}{c}01.01 . \\
2023\end{array}$ & 12 \\
\hline 9 & $\begin{array}{l}\text { Irkutsk } \\
\text { CHP-10 }\end{array}$ & TG-2 & 150 & $\begin{array}{c}01.01 . \\
2023\end{array}$ & 10 \\
\hline 9 & $\begin{array}{l}\text { Novo- } \\
\text { Irkutsk TPP }\end{array}$ & TG-3 & 175 & $\begin{array}{c}01.01 . \\
2023\end{array}$ & 11 \\
\hline \multicolumn{6}{|c|}{2024} \\
\hline 6 & $\begin{array}{l}\text { Krasnoyarsk } \\
\text { TPP } 1\end{array}$ & TG-10 & 87 & $\begin{array}{c}01.01 . \\
2024\end{array}$ & 6 \\
\hline 6 & $\begin{array}{l}\text { Krasnoyarsk } \\
\text { TPP } 1\end{array}$ & TG-15 & 70 & $\begin{array}{c}01.12 . \\
2024\end{array}$ & 11 \\
\hline 6 & $\begin{array}{l}\text { Krasnoyarsk } \\
\text { TPP } 1\end{array}$ & TG-16 & 70 & $\begin{array}{c}01.12 . \\
2024\end{array}$ & 11 \\
\hline 6 & $\begin{array}{l}\text { Krasnoyarsk } \\
\text { TPP } 3\end{array}$ & TG-2 & 110 & $\begin{array}{c}01.12 . \\
2024\end{array}$ & 12 \\
\hline
\end{tabular}




\begin{tabular}{|c|c|c|c|c|c|}
\hline 9 & $\begin{array}{l}\text { Irkutsk } \\
\text { TPP-9 }\end{array}$ & TG-6 & 60 & $\begin{array}{c}01.01 . \\
2024\end{array}$ & 10 \\
\hline 9 & $\begin{array}{l}\text { Irkutsk } \\
\text { TPP-10 }\end{array}$ & TG-7 & 150 & $\begin{array}{c}01.05 . \\
2024\end{array}$ & 10 \\
\hline 9 & $\begin{array}{l}\text { Irkutsk TPP } \\
-10\end{array}$ & TG-8 & 150 & $\begin{array}{c}01.01 . \\
2024\end{array}$ & 10 \\
\hline 9 & $\begin{array}{l}\text { Irkutsk TPP } \\
-11\end{array}$ & TG-3 & 50 & $\begin{array}{c}01.01 . \\
2024\end{array}$ & 11 \\
\hline \multicolumn{6}{|c|}{2025} \\
\hline 6 & $\begin{array}{l}\text { Krasnoyarsk } \\
\text { TPP } 1\end{array}$ & TG-15 & 70 & $\begin{array}{c}01.01 . \\
2025\end{array}$ & 10 \\
\hline 6 & $\begin{array}{l}\text { Krasnoyarsk } \\
\text { TPP } 1\end{array}$ & TG-16 & 70 & $\begin{array}{c}01.01 . \\
2025\end{array}$ & 10 \\
\hline 6 & $\begin{array}{l}\text { Krasnoyarsk } \\
\text { TPP } 3\end{array}$ & TG-2 & 110 & $\begin{array}{c}01.01 . \\
2025\end{array}$ & 11 \\
\hline 9 & $\begin{array}{l}\text { Irkutsk TPP } \\
-10\end{array}$ & TG-7 & 150 & $\begin{array}{c}01.01 . \\
2025\end{array}$ & 2 \\
\hline 1 & $\begin{array}{l}\text { Omsk TPP- } \\
4\end{array}$ & TG-9 & 135 & $\begin{array}{c}01.01 . \\
2025\end{array}$ & 12 \\
\hline 3 & ТРР СХК & TG-1 & 60 & $\begin{array}{c}01.07 . \\
2025\end{array}$ & 6 \\
\hline 3 & $\begin{array}{l}\text { TPP } \\
\text { Seversky } \\
\text { Chemical } \\
\text { Combine }\end{array}$ & TG-2 & 60 & $\begin{array}{c}01.07 . \\
2025\end{array}$ & 6 \\
\hline 4 & $\begin{array}{l}\text { Biysk TPP - } \\
1\end{array}$ & TG-6 & 110 & $\begin{array}{c}01.12 . \\
2025\end{array}$ & 9 \\
\hline 9 & $\begin{array}{l}\text { Ust-Ilim } \\
\text { TPP }\end{array}$ & TG-3 & 110 & $\begin{array}{c}01.05 . \\
2025\end{array}$ & 9 \\
\hline 9 & $\begin{array}{l}\text { Irkutsk ТРP } \\
\text { ТЭЦ-10 }\end{array}$ & TG-5 & 150 & $\begin{array}{c}01.12 . \\
2025\end{array}$ & 9 \\
\hline 12 & Chita TPP-1 & TG-4 & 87 & $\begin{array}{c}01.11 . \\
2025\end{array}$ & 7 \\
\hline 12 & $\begin{array}{l}\text { Chita TPP - } \\
1\end{array}$ & TG-3 & 80 & $\begin{array}{c}01.12 . \\
2025\end{array}$ & 10 \\
\hline
\end{tabular}

Table 4 shows an example of adjusting the timing of modernization of units for 2024. The column "Date of modernization commencement" in bold represents the modified dates compared to the dates of the commencement of modernization in the regulatory documents presented in Table 3 .

Table 4. Adjustment of terms for modernization of generating equipment in 2024.

\begin{tabular}{|c|c|c|c|c|c|}
\hline $\begin{array}{l}\text { Name of } \\
\text { generatin } \\
\text { g facility }\end{array}$ & $\begin{array}{l}\text { No. } \\
\text { Equip } \\
\text { ment } \\
\text { Statio } \\
\mathrm{n} \\
\end{array}$ & $\begin{array}{l}\text { Installed } \\
\text { capacity } \\
\text { of the } \\
\text { unit, } \\
\text { MW }\end{array}$ & $\begin{array}{c}\text { Moder } \\
\text { nizatio } \\
\text { n Start } \\
\text { Date }\end{array}$ & $\begin{array}{l}\mathrm{Nu} \\
\text { mbe } \\
\mathrm{r} \text { of } \\
\text { mon } \\
\text { ths }\end{array}$ & $\begin{array}{l}\text { Upgra } \\
\text { de } \\
\text { End } \\
\text { Date }\end{array}$ \\
\hline $\begin{array}{l}\text { Krasnoya } \\
\text { rsk TPP } 1\end{array}$ & $\begin{array}{c}\text { TG- } \\
10\end{array}$ & 87 & 01.04 & 6 & 30.10 \\
\hline $\begin{array}{l}\text { Krasnoya } \\
\text { rsk TPP } 1\end{array}$ & $\begin{array}{l}\text { TG- } \\
15\end{array}$ & 70 & 01.12 & 11 & \multirow{2}{*}{$\begin{array}{c}\text { moder } \\
\text { nizatio } \\
\mathrm{n} \\
\text { postpo }\end{array}$} \\
\hline $\begin{array}{l}\text { Krasnoya } \\
\text { rsk TPP } 1\end{array}$ & $\begin{array}{c}\text { TG- } \\
16\end{array}$ & 70 & 01.12 & 11 & \\
\hline
\end{tabular}

\begin{tabular}{|c|c|c|c|c|c|}
\hline $\begin{array}{c}\text { Krasnoya } \\
\text { rsk TPP 3 }\end{array}$ & TG-2 & 110 & 01.12 & 12 & $\begin{array}{c}\text { ned to } \\
25\end{array}$ \\
\hline $\begin{array}{c}\text { Irkutsk } \\
\text { TPP -9 }\end{array}$ & TG-6 & 60 & $\mathbf{0 1 . 0 2}$ & 10 & 30.11 \\
\hline $\begin{array}{c}\text { Irkutsk } \\
\text { TPP -10 }\end{array}$ & TG-7 & 150 & $\mathbf{0 1 . 0 2}$ & 10 & 30.11 \\
\hline $\begin{array}{c}\text { Irkutsk } \\
\text { TPP 10 }\end{array}$ & TG-8 & 150 & $\mathbf{0 1 . 0 3}$ & 10 & 30.12 \\
\hline $\begin{array}{c}\text { Irkutsk } \\
\text { TPP -11 }\end{array}$ & TG-3 & 50 & $\mathbf{0 1 . 0 2}$ & 11 & 30.12 \\
\hline
\end{tabular}

Analyzing the results obtained, we can conclude that the period from April to October with the highest adequacy indicators for each of the considered years (2023-2025) coincides or mainly coincides with the period of the lowest loads. In March and November, the probability of a fail-free operation is at a fairly high level. In December, the situation with this indicator worsens somewhat, but it is still high $(0.99 \ldots-0.999 \ldots)$. And in January and February, these indicators are quite low $(0.90 \ldots-0.98 \ldots)$. Periods of modernization are adjusted, maintaining their duration. If by duration it is possible to place them in the field of high adequacy, then they are placed there.

The indicative result of adjusting the timing of modernization of generating equipment is the value of the mathematical expectation of under-supply of electricity. Tables 5-10 show the probabilities of failfree operation and the mathematical expectation of under-supply of electricity received as a result of settlements for 2023-2025 according to plans for modernization of generating equipment and with the adjustment of their terms.

Table 5. The results of the calculations taking into account the modernization of units according to plan in 2023.

\begin{tabular}{|c|c|c|}
\hline $\begin{array}{c}\text { No. } \\
\text { zone }\end{array}$ & $\begin{array}{c}\text { Probability of a } \\
\text { fail-free } \\
\text { operation }\end{array}$ & $\begin{array}{c}\text { The m.e. of under- } \\
\text { supply of electricity } \\
\text { MW h }\end{array}$ \\
\hline 1 & 0,987308 & 26134,1 \\
\hline 2 & 0,996307 & 605,5 \\
\hline 3 & 0,996170 & 1345,9 \\
\hline 4 & 0,996311 & 638,9 \\
\hline 5 & 0,996422 & 750,4 \\
\hline 6 & 0,99636 & 840,9 \\
\hline 7 & 0,997362 & 429,6 \\
\hline 8 & 0,995664 & 2919,1 \\
\hline 9 & 0,995694 & 6233,0 \\
\hline 10 & 0,809202 & 10172,2 \\
\hline
\end{tabular}




\begin{tabular}{|c|c|c|}
\hline 11 & 0,992951 & 4204,4 \\
\hline 12 & 0,934592 & 72070,9 \\
\hline IPS & 0,781171 & 126344,8 \\
\hline
\end{tabular}

Table 6. The results of the calculations, taking into account the adjustment of the terms of modernization of units in 2023

\begin{tabular}{|c|c|c|}
\hline $\begin{array}{l}\text { No. } \\
\text { zone }\end{array}$ & $\begin{array}{c}\text { Probability of a } \\
\text { fail-free } \\
\text { operation }\end{array}$ & $\begin{array}{l}\text { The m.e. of under- } \\
\text { supply of electricity } \\
\text { MW h }\end{array}$ \\
\hline 1 & 0,989189 & 21523,4 \\
\hline 2 & 0,997087 & 487,7 \\
\hline 3 & 0,996997 & 1156,1 \\
\hline 4 & 0,997065 & 505,2 \\
\hline 5 & 0,997194 & 630,5 \\
\hline 6 & 0,997124 & 707,0 \\
\hline 7 & 0,997895 & 290,7 \\
\hline 8 & 0,996595 & 2284,6 \\
\hline 9 & 0,996684 & 4270,9 \\
\hline 10 & 0,808671 & 9446,5 \\
\hline 11 & 0,99438 & 3244,9 \\
\hline 12 & 0,936554 & 66474,7 \\
\hline IPS & 0,781422 & 111022,2 \\
\hline
\end{tabular}

Table 7. The results of the calculations taking into account the modernization of units according to plan in 2024.

\begin{tabular}{|c|c|c|}
\hline $\begin{array}{c}\text { No. } \\
\text { zone }\end{array}$ & $\begin{array}{c}\text { Probability of a } \\
\text { fail-free } \\
\text { operation }\end{array}$ & $\begin{array}{c}\text { The m.e. of under- } \\
\text { supply of electricity } \\
\text { MW h }\end{array}$ \\
\hline 1 & 0.988387 & 23446.5 \\
\hline 2 & 0.996750 & 605.1 \\
\hline 3 & 0.996634 & 1196.8 \\
\hline 4 & 0.996726 & 574.7 \\
\hline 5 & 0.996824 & 702.1 \\
\hline 6 & 0.996778 & 768.4 \\
\hline
\end{tabular}

\begin{tabular}{|c|c|c|}
\hline 7 & 0.997662 & 304.4 \\
\hline 8 & 0.996219 & 2531.1 \\
\hline 9 & 0.996252 & 4962.7 \\
\hline 10 & 0.809111 & 9659 \\
\hline 11 & 0.993715 & 3732.1 \\
\hline 12 & 0.935852 & 69100.1 \\
\hline IPS & 0.781349 & 117583 \\
\hline
\end{tabular}

Table 8. The results of the calculations, taking into account the adjustment of the terms of modernization of units in 2024.

\begin{tabular}{|c|c|c|}
\hline $\begin{array}{l}\text { No. } \\
\text { zone }\end{array}$ & $\begin{array}{c}\text { Probability of a } \\
\text { fail-free } \\
\text { operation }\end{array}$ & $\begin{array}{l}\text { The m.e. of under- } \\
\text { supply of electricity } \\
\text { MW h }\end{array}$ \\
\hline 1 & 0.991550 & 15974.7 \\
\hline 2 & 0.998021 & 358.7 \\
\hline 3 & 0.997996 & 781.5 \\
\hline 4 & 0.998014 & 359.6 \\
\hline 5 & 0.998097 & 407.7 \\
\hline 6 & 0.998046 & 438.3 \\
\hline 7 & 0.998503 & 265.3 \\
\hline 8 & 0.997573 & 1569.7 \\
\hline 9 & 0.997741 & 2382.8 \\
\hline 10 & 0.808300 & 8857.6 \\
\hline 11 & 0.995755 & 2339.9 \\
\hline 12 & 0.938384 & 61348.1 \\
\hline IPS & 0.781816 & 95084,0 \\
\hline
\end{tabular}

Table 9. The results of the calculations taking into account the modernization of units according to plan in 2025 .

\begin{tabular}{|c|c|c|}
\hline $\begin{array}{c}\text { No. } \\
\text { zone }\end{array}$ & $\begin{array}{c}\text { Probability of a } \\
\text { fail-free } \\
\text { operation }\end{array}$ & $\begin{array}{c}\text { The m.e. of under- } \\
\text { supply of electricity } \\
\text { MW h }\end{array}$ \\
\hline 1 & 0,981878 & 40739,6 \\
\hline 2 & 0,996607 & 546,0 \\
\hline
\end{tabular}




\begin{tabular}{|c|c|c|}
\hline 3 & 0,996564 & 1436,9 \\
\hline 4 & 0,996629 & 526,4 \\
\hline 5 & 0,996744 & 772,6 \\
\hline 6 & 0,996698 & 377,8 \\
\hline 7 & 0,997584 & 2416,5 \\
\hline 8 & 0,996031 & 4753,7 \\
\hline 9 & 0,996194 & 9725,8 \\
\hline 10 & 0,810172 & 3730,1 \\
\hline 11 & 0,992625 & 122255,4 \\
\hline 12 & 0,896632 & 188120,1 \\
\hline IPS & 0,763576 & \\
\hline
\end{tabular}

Table 10. The results of the calculations, taking into account the adjustment of the terms of modernization of units in 2025.

\begin{tabular}{|c|c|c|}
\hline $\begin{array}{l}\text { No. } \\
\text { zone }\end{array}$ & $\begin{array}{c}\begin{array}{c}\text { Probability of a } \\
\text { fail-free } \\
\text { operation }\end{array} \\
\end{array}$ & $\begin{array}{l}\text { The m.e. of under- } \\
\text { supply of electricity } \\
\text { MW h }\end{array}$ \\
\hline 1 & 0,981670 & 40561,9 \\
\hline 2 & 0,996718 & 483,3 \\
\hline 3 & 0,996683 & 1405,4 \\
\hline 4 & 0,996693 & 474,0 \\
\hline 5 & 0,996818 & 780,0 \\
\hline 6 & 0,996840 & 804,1 \\
\hline 7 & 0,997634 & 317,2 \\
\hline 8 & 0,996097 & 2290,3 \\
\hline 9 & 0,996394 & 4167,8 \\
\hline 10 & 0,809292 & 9764,8 \\
\hline 11 & 0,992727 & 3503,4 \\
\hline 12 & 0,925088 & 79047,4 \\
\hline IPS & 0,770604 & 143599,7 \\
\hline
\end{tabular}

The results of adjusting the timing of modernization of generating equipment showed:

- for 2023 the mathematical expectation of undersupply of electricity of the IPS as a whole, taking into account modernization according to the plan, is 126344.8, and with an adjustment of terms - 111022.2 MW h. That is, the mathematical expectation of undersupply of electricity of IPS decreased by $15322.6 \mathrm{MWh}$, which is approximately $12 \%$.

- for 2024 the mathematical expectation of undersupply of electricity of the IPS as a whole, taking into account modernization according to plan, is 117583 , and with an adjustment of the terms - $94773 \mathrm{MW} \mathrm{h}$. That is, for IPS the mathematical expectation of under-supply of electricity decreased by $22810 \mathrm{MWh}$, which is approximately $20 \%$.

- for 2025 the mathematical expectation of undersupply of electricity of the IPS as a whole, taking into account modernization according to plan, is 188,120.1, and with an adjustment of the terms $-143,599.7 \mathrm{MW}$ h. That is, the mathematical expectation of under-supply of electricity of the IPS decreased by $44520.4 \mathrm{MW} \mathrm{h}$, which is approximately $23.6 \%$.

Analyzing the probabilities of a fail-free operation, we can conclude that their values correlate with the values of the mathematical expectation of under-supply of electricity and taking into account modernization according to plans is slightly less than in calculations with adjustment of the terms of modernization. An exception in some cases are the most problematic nodes. There are objective reasons for this.

The calculation results for all the years analyzed show that the application of the proposed methodic, based on indicators of adequacy, makes it possible to increase the efficiency of decision-making. As shown above, the increase in efficiency is most evident in terms of the mathematical expectation of under-supply of electricity.

\section{Conclusions}

The modernization of electric power facilities makes it possible to increase their efficiency. During modernization, facilities are decommissioned for a certain period of time. The decommissioning of facilities affects the adequacy of the EPS. It is important that the time period is optimally predicted for decommissioning of EPS. At the same time, minimal damage was caused to the EPSs during this period. The article proposes a methodic for determining the procedure for decommissioning for the purpose of modernization of generating equipment. At the same time, the maximum possible level of adequacy of EPSs should be ensured.

Experimental studies have shown the effectiveness of the methodic.

The research was carried out under State Assignment 17.5.3 (reg. no, AAAAA-A17-117030310450-3), with the financial support by the Russian Foundation for Basic Research within the framework of the scientific project No. 18-58-06001. 


\section{References}

1. "On the selection of projects for the modernization of generating facilities of thermal power plants." Decree of the Government of the Russian Federation of January 25, 2019 No. 43. (in Russia)

2. "The list of generating objects, the capacity of which is supplied under the purchase and sale (supply) agreements of the capacity of modernized generating objects." Order of the Government of the Russian Federation of 02.08.2019 No. 1713-r. (In Russia)

3. "The procedure for the selection of projects for the modernization of generating equipment for thermal power plants" was approved on September 20, 2018 (Minutes No. 20/2018 of the meeting of the Supervisory Board of NP Market Council Association). (In Russia)

4. G. F. Kovalev, L. M. Lebedeva. Reliability of Power Systems. Springer. 237 p. (2019),

5. R. Billinton, W. Li. Reliability Assessment of Electric Power Systems Using Monte Carlo Methods. Springer. 361 p. (1994)

6. Methodical Instructions for designing the development of power systems. Izd-vo NTs ENAS, Moscow. (2003). (In Russia) 